\title{
STATUS HUKUM TANAH HAK MILIK BAGI AHLI WARIS YANG PINDAH KEWARGANEGARAAN MENJADI WARGA NEGARA ASING
}

\author{
Agnes Geraldine Olga Supriyana, I Nyoman Putu Budiartha, I Ketut Sukadana \\ Fakultas Hukum Universitas Warmadewa, Denpasar-Bali, Indonesia \\ olgaguapa20@gmail.com, budiartha59@gmail.com, sukadanaketut1966@gmail.com
}

\begin{abstract}
Abstrak
Warga negara Indonesia yang telah pindah kewarganegaraan karena perkawinan campuran dengan warga negara lain yang memperoleh hak milik karena warisan seharusnya wajib melepaskan hak itu dalam jangka waktu satu tahun. Apabila tidak dilepaskan maka hak tersebut hilang karena hukum dan tanahnya jatuh pada negara. Namun pada kenyataannya hak milik tersebut ada yang belum dilepas. Penelitian ini dirumuskan untuk mengetahui status hak milik atas tanah yang tidak dilepas oleh ahli waris yang menjadi warga negara asing dan untuk mengetahui upaya hukum yang dilakukan oleh ahli waris yang pindah kewarganegaraan menjadi warga negara asing dalam melepas hak milik atas tanah yang diperoleh karena warisan. Metode penelitian yang digunakan dalam penelitian ini adalah metode penelitian hukum normatif. Hasil penelitian menunjukkan bahwa status hak milik atas tanah yang tidak dilepas oleh ahli waris yang menjadi warga negara asing menjadi hilang karena hukum. Ini terjadi setelah melewati jangka waktu satu tahun, dan tanah tersebut menjadi tanah Negara. Kemudian, upaya hukum yang dilakukan oleh ahli waris tersebut dalam melepas hak milik atas tanah yang diperoleh karena warisan adalah mengajukan permohonan untuk memperoleh lagi kewarganegaraan Indonesia atau tetap menjadi warga negara asing bertempat tinggal di Indonesia sehingga setelah satu tahun dapat memperoleh hak pakai atau peralihan hak milik itu dapat dilakukan melalui jual beli.
\end{abstract}

Kata Kunci: Ahli waris; Hak milik atas tanah; Perubahan kewarganegaraan; Upaya hukum

\begin{abstract}
Indonesian citizens who have transferred citizenship due to mixed marriages with other citizens who obtain property rights due to inheritance should be obliged to relinquish this right within one year. If it is not released then the right is lost because the law and the land fall to the state. However, in reality some of these property rights have not been released. This research is formulated to determine the status of land ownership rights that are not released by heirs who become foreign nationals and to find out the legal efforts taken by heirs who have transferred citizenship to become foreign citizens in releasing their ownership rights over land acquired due to inheritance. The research method used in this research is normative legal research method. The results showed that the status of land ownership rights that were not released by heirs who became foreign citizens was lost due to the law. This occurs after a period of one year, and the land becomes State land. Then, the legal effort made by the heirs in releasing ownership rights over the land obtained due to inheritance is to apply for more Indonesian citizenship or to remain a foreign citizen residing in Indonesia, so after one year they can obtain use rights or transfer of property rights. It can be done through buying and selling.
\end{abstract}

Keywords: Heirs; Ownership rights to land; Change of citizenship; Legal effort

\section{PENDAHULUAN}

Tingginya perpindahan penduduk dari satu negara ke negara lainnya dapat menyebabkan terjadinya perpindahan kewarganegaraan, begitu pula dengan warga negara Indonesia karena alasan pendidikan, pekerjaan, pernikahan, maupun alasan lainnya memilih untuk menjadi warga negara asing (Charity, 2016). Orang asing yang datang ke Indonesia berasal dari berbagai negara dan mampu bergaul dengan penduduk setempat. Adanya interaksi yang terjadi sering kali mengakibatkan perkawinan. Perkawinan antara dua orang yang memiliki perbedaan kewarganegaraan disebut dengan perkawinan campuran. Pada saat ini sudah banyak terjadi perkawinan campuran antara orang berkewarganegaraan Indonesia dengan Warga Negara Asing (Arliman S, 2017; Djawas \& Nurzakia, 2018). Persoalan yang sering timbul dalam perkawinan campuran adalah masalah kewarganegaraan dan waris. Namun 
dengan perpindahan dan perbedaan kewarganegaraan bukan sebagai penghalang untuk hal pewarisan dan tidak serta merta menghilangkan ikatan darah dengan keluarga yang masih berada dan menetap di Indonesia (Rampay, 2015).

Berikut ini merupakan contoh perkawinan campuran yang berkaitan dengan penelitian ini. Si A merupakan warga negara Indonesia yang menikah dengan si B warga negara Australia dan saat ini si A dan si B tinggal di Australia selama 7 tahun. Setelah si A menikah dengan si B status kewarganegaraan berpindah mengikuti kewarganegaraan si B. Pernikahan mereka belum dikaruniai anak. Suatu saat setelah pernikahan mereka tersebut, orang tua dari si A meninggal dunia dan meninggalkan beberapa warisan, yang mana apabila dilihat dari silsilah keluarga si A merupakan pewaris tunggal. Menurut KUHPerdata, ahli waris tetap menerima waris dari pewaris yang meninggal dunia tanpa memandang status kewarganegaraan. Saat ini si A telah menerima beberapa warisan tersebut dan menguasai kurang lebih 3 tahun, yang seharusnya menurut hukum di Indonesia Warga negara asing tidak berhak memiliki hak milik berupa tanah di Indonesia. Maka terhadap UUPA yang menyatakan orang asing memperoleh hak milik karena warisan wajib melepas hak itu dalam jangka waktu 1 tahun, apabila lebih dari jangka waktu hak milik tersebut tak dilepas maka hak tersebut dihapus karena hukum serta tanahnya menjadi milik negara, namun terkait undang-undang kewarganegaraan yang menyatakan terhadap status kewarganegaraan yang mana menitik beratkan kepada orang asing eks warga negara Indonesia yang melakukan perkawinan campuran bisa mengajukan surat pernyataan perihal tujuannya untuk bertahan berkewarganegaraan Indonesia. Oleh sebab itu, kedua peraturan perundang-undangan tersebut sejatinya tidak terkait satu sama lain dan mengakibatkan terjadinya konflik norma atau pertentangan norma mengenai maksud orang asing yang tidak dapat memperoleh hak milik atas tanah melalui pewarisan.

Berdasarkan pemaparan latar belakang masalah di atas, dapat dirumuskan tujuan dari penelitian ini, yakni untuk mengetahui status hak milik atas tanah yang tidak dilepas oleh ahli waris yang menjadi warga negara asing, dan dan untuk mengetahui upaya hukum yang dilakukan oleh ahli waris yang pindah kewarganegaraan menjadi warga negara asing dalam melepas hak milik atas tanah yang diperoleh karena warisan.

\section{METODE PENELITIAN}

Penilitian ini ditulis menggunakan jenis penelitian hukum normatif yakni dengan mengkaji dan melakukan studi pustaka seperti peraturan perundang-undangan serta literature penunjang yang berkaitan dengan permasalahan pokok dalam penelitian ini, jenis pendekatan dipergunakan pendekatan perundang-undangan dan konseptual. Untuk menunjang pembahasan terhadap permasalahan, maka ada beberapa bahan hukum yang dijadikan sebagai sumber data dalam penelitian ini, yakni bahan hukum primer yang bersumber pada peraturan perundang-undangan yang sesuai masalah yang di bahas di dalam penelitian. Kemudian, bahan hukum sekunder yang bersumber pada kepustakaan, jurnal hukum, majalah, dan surat kabar. Teknik penggabungan sumber-sumber bahan hukum melalui pendataan, pembelajaran dan pendalaman bahan hukum primer dan sekunder sesuai dengan penelitian yaitu dengan membuat tulisan dan melakukan pengelompokan terhadap bahanbahan tersebut. Pengaturan perlu dilakukan secara horizontal seraya meneliti rumusan perundangundangannya dalam ini adalah peraturan perundang-undangan. Hal ini dilakukan untuk mempermudah melakukan analisis terhadap obyek penelitian.

\section{HASIL DAN PEMBAHASAN}

\section{Status Hak Milik atas Tanah yang Tidak Dilepas oleh Ahli Waris yang Menjadi Warga Negara Asing}

Warga negara menurut undang-undang kewarganegaraan yaitu warga suatu negara yang ditetapkan menurut perundang-undangan. Yang dapat dinyatakan sebagai warga negara Indonesia ialah orang Indonesia asli dan orang asing yang telah sah dimata undang-undang tercatat sebagai warga negara. Orang asing bisa didefinisikan sebagai orang yang tidak tercatat sebagai warga negara Indonesia dan sedang berdiam di Indonesia (Supramono, 2012). Menurut kamus istilah hukum, orang merupakan pendukung hukum atau subjek hukum yang dapat mengadakan hubungan hukum dan melakukan tindakan hukum, yang menimbulkan hak dan kewajiban (Yusticia, 2018). Meskipun pada dasarnya hanya orang Indonesia lah yang bisa memiliki tanah, namun dalam keadaan khusus selama waktu tertentu seperti yang dirumuskan UUPA Pasal 21 ayat 3, masih membolehkan bagi orang asing 
dan warga negara Indonesia yang berkewarganegaraan ganda memiliki tanah hak milik baik karena warisan maupun bukan warisan.

Dikatakan dalam UUPA bahwa dalam kurun waktu satu tahun hak milik wajib dilepaskan, dan jika hak tersebut tidak dilepaskan maka warga negara asing itu telah melanggar pasal tersebut, sehingga hak itu menjadi hapus dan tanahnya dikuasai langsung oleh negara. Eks pemilik yang mempunyai hak milik atas tanah waris tersebut setelah itu diberi kesempatan untuk meminta lagi tanah yang bersangkutan dengan hak dapat dimilikinya, yaitu bagi warga negara asing hak pakai dan bagi warga negara Indonesia yang berkewarganegaraan ganda hak pakai, hak guna usaha, atau hak guna bangunan.

\section{Upaya Hukum yang Dilakukan oleh Ahli Waris yang Pindah Kewarganegaraan Menjadi Warga Negara Asing dalam Melepas Hak Milik Atas Tanah yang Diperoleh Karena Warisan}

Warga negara asing terbagi menjadi orang asing yang tidak memiliki hubungan dengan Indonesia dan orang-orang asing yang memiliki kaitan dengan Indonesia disebabkan faktor-faktor seperti keturunan ataupun penggantian warga negara. Lalu orang asing yang datang dan berkeinginaan tinggal di Indonesia terbagi atas dua golongan, yakni orang asing yang tinggal dalam jangka waktu tertentu serta orang asing yang akan menetap di Indonesia (Sumardjono, 2009). Dalam hal terjadinya perbedaan kewarganegaraan antara pewaris dengan ahli waris, hal ini tidak menyebabkan gugur atau hilangnya ataupun menghalangi seseorang untuk mendapatkan hak mewaris seseorang selaku ahli waris dari pewaris (Sebastian, 2018).

Hukum waris yaitu hukum yang mengontrol mengenai beralihnya harta kekayaan yang ditinggalkan oleh seorang yang meninggal dunia juga dampakya kepada ahli waris (Purangin, 1997).Terkait pemindahan hak atas tanah dari pewaris ke ahli warisnya yang mempunyai kewarganegaraan berbeda, terdapat adanya pembatasan- pembatasan terkait pemindahan hak atas tanah tersebut yaitu membatasi terkait kecakapan berhak dalam hal ini yaitu kewarganegaraan, menurut UUPA disebutkan sejatinya hanya warga negara Indonesia yang bisa memiliki keterkaitan sepenuhnya terhadap air, bumi, dan ruang angkasa. Pernyataan tersebut kemudian diperjelas kembali dalam UUPA hanya warga negara Indonesia yang dapat mempunyai hak milik. Hal ini menunjukkan bahwa bagi WNA yang berkedudukan di Indonesia dapat diberikan hak pakai sebagaimana tercantum dalam Pasal 42 Undang-Undang Nomor 5 tahun 1960 tentang Pokok Agraria (Purnamasari, 2014).

Upaya hukum yang dilakukan oleh ahli waris yang menjadi warga negara asing terkait hak milik atas tanah kepunyaanya oleh karena warisan ada beberapa cara, yaitu :

a. Ahli waris yang telah pindah kewarganegaraan dan berhak menerima warisan dari pewaris yang merupakan warga negara Indonesia bisa meminta permohonan kembali tentang keinginannya untuk tetap menjadi warga negara Indonesia sesuai ketentuan UU Kewarganegaraan Indonesia dan PP tentang Tata Cara Memperoleh, Kehilangan, Pembatalan, dan Memperoleh Kembali Kewarganegaraan Republik Indonesia sehingga ahli waris yang telah menjadi warga negara asing tersebut berhak memperoleh kembali hak-hak sebagaimana warga negara Indonesia.

b. Ahli waris yang tetap tercatat sebagai warga negara asing namun bertempat tinggal di Indonesia dan tidak mengurus atau menjual sehingga sudah melewati limit waktu 1 tahun dari ketentuan UUPA, maka tanah tersebut jatuh pada negara tetapi orang asing itu dapat memakai hak pakai demi membangun bangunan sesuai perumusan dalam UUPA.

c. Peralihan hak milik karena warisan oleh ahli waris yang menjadi warga negara asing bisa dilakukan melalui proses jual beli atau hibah pada warga negara Indonesia dalam waktu 1 tahun, sehingga ahli waris yang pindah kewarganegaraan tersebut tidak lagi memiliki properti di Indonesia dan hanya memperoleh uang dari hasil menjual tersebut.

Ahli waris yang mempunyai kewarganegaraan berbeda dan berhak menerima warisan dari pewaris yang merupakan warga negara Indonesia bisa mengajukan permohonan kembali tentang keinginannya untuk tetap menjadi warga negara Indonesia. Pernyataan ingin tetap menjadi warga negara Indonesia di atur dalam Pasal 55-58 PP tentang Tata Cara Memperoleh, Kehilangan, Pembatalan, dan Memperoleh Kembali Kewarganegaraan Republik Indonesia. Perempuan atau lakilaki eks warga negara Indonesia yang menjadi warga negara asing hendak kukuh menjadi warga negara Indonesia bisa mengajukan surat pernyataan setelah tiga tahun dari tanggal perkawinan berlangsung, hal ini diatur dalam pasal 55 ayat 1 PP No. 2 Tahun 2007 jo Pasal 26 ayat 3 UU No. 12 Tahun 2006 tentang Kewarganegaraan Indonesia. Maka UUPA yang menyatakan warga negara asing 
yang mendapatkan hak milik akibat dari warisan harus melepas hak itu dalam batas waktu 1 tahun, apabila lebih dari jangka waktu dan tetap tidak dilepas maka hak tersebut mesti dihapuskan lantaran hukum dan tanahnya jatuh pada negara, namun terkait hal tersebut pada Undang-Undang Kewarganegaraan menyatakan terhadap status kewarganegaraan yang mana warga negara asing eks warga negara Indonesia menitik beratkan terhadap warga negara Indonesia yang telah menjadi Warga negara asing karena melakukan perkawinan campuran dapat melakukan pengajuan surat pernyataan tentang keinginan untuk tetap menjadi warga negara Indonesia.

Apabila pewaris telah meninggal maka menurut hukum dapat dikatakan otomatis hak dari pewaris berpindah ke tangan ahli waris. Para ahli waris yang dengan sendirinya karena hukum mendapat hak milik dari orang yang dinyatakan telah meninggal, sebaiknya bila ahli waris langsung mendaftar tanahnya. Permohonan mendaftarkan warisan dilakukan oleh ahli waris atau yang telah mendapatkan kuasa oleh ahli waris di kantor pertanahan. Bagi orang asing yang menetap di Indonesia bisa menggunakan hak pakai untuk membangun bangunan. Dalam memberikan hak pakai oleh pemilik hak dalam kurun waktu tertentu kepada orang asing maupun warga negara Indonesia, dilarang diterapkan syarat yang bisa menjatuhkan salah satu pihak, dimana pemberi hak pakai sebagai pemilik atas tanah dan penerima hak pakai wajib mematuhi hak dan kewajiban yang sudah disetujui dalam perjanjian.

Peralihan hak milik atas tanah bagi orang asing eks WNI yang menerima hak warisan tersebut bisa dilakukan melalui jual beli atau hibah pada warga negara Indonesia, dan apabila dalam waktu 1 tahun tanah itu tidak dijual maka tanahnya menjadi kepunyaan negara. Hal ini dikarenakan berdasarkan Undang-Undang Pokok Agraria, seorang warga negara asing tidak dapat memiliki tanah dengan status hak milik di Indonesia. Dengan dilakukannya penjualan hak atas tanah yang seharusnya diwarisi tersebut, maka untuk selanjutnya uang hasil penjualan berupa uang diberikan kepada ahli waris yang pindah kewarganegaraan menjadi warga negara asing tersebut. Peralihan hak milik oleh ahli waris yang menjadi warga negara asing melalui jual beli atau hibah pada warga negara Indonesia dalam jangka waktu setahun melalui pejabat berwenang yaitu PPAT yang selanjutnya disahkan lewat Badan Pertanahan Nasional sesuai aturan dalam PP tentang Pendaftaran Tanah.

\section{SIMPULAN DAN SARAN}

\section{Simpulan}

Berdasarkan hasil penelitian di atas, dapat disimpulkan bahwa status hak milik atas tanah yang tidak dilepas oleh ahli waris yang menjadi warga negara asing adalah menjadi hapus karena hukum setelah melewati jangka waktu satu tahun dari ketentuan UUPA dan tanahnya dikuasai langsung oleh negara. Setelah itu eks pemilik yang memiliki hak milik atas tanah waris itu diberikan kesempatan adanya permintaan kembali tanah bersangkutan dengan hak yang bisa dimilikinya, yaitu untuk warga negara asing hak pakai dan bagi warga negara Indonesia yang berkewarganegaraan ganda hak guna usaha, hak guna bangunan, atau hak pakai. Kemudian, upaya hukum yang dilakukan oleh ahli waris yang pindah kewarganegaraan menjadi warga negara asing dalam melepas hak milik atas tanah yang diperoleh karena warisan, yaitu : Ahli waris yang pindah kewarganegaraan berhak menerima warisan dari pewaris yang merupakan warga negara Indonesia bisa mengajukan permohonan mengenai keinginannya untuk tetap menjadi warga negara Indonesia sesuai ketentuan UU Kewarganegaraan Indonesia dan PP tentang Tata Cara Memperoleh, Kehilangan, Pembatalan, dan Memperoleh Kembali Kewarganegaraan Republik Indonesia sehingga ahli waris eks warga negara Indonesia tersebut berhak atas kepimilikannya lagi hak-hak sebagai warga negara Indonesia; Ahli waris yang merupakan warga negara asing namun bertempat tinggal di Indonesia dan tidak mengurus atau menjual sehingga sudah lewat batas waktu 1 tahun dari ketentuan UUPA, maka tanah tersebut jatuh pada negara tetapi orang asing itu dapat memakai hak pakai dalam membangun bangunan sesuai dengan UUPA; Peralihan hak milik karena warisan oleh ahli waris yang menjadi warga negara asing bisa dilakukan melalui proses jual beli atau hibah pada warga negara Indonesia di dalam jangka waktu 1 tahun, sehingga ahli waris yang pindah kewarganegaraan tersebut tidak lagi memiliki properti di Indonesia dan hanya memperoleh uang dari hasil menjual tersebut.

\section{Saran}

Adapun saran yang hendak disampaikan, yakni warga negara Indonesia yang telah menjadi warga negara asing agar secara sukarela melepas hak milik atas tanah tersebut sesuai dengan ketentuan di dalam Undang-Undang Pokok Agraria. Kemudian, pemerintah hendaknya membuat perbaikan dan 
perubahan tentang jangka waktu di dalam ketentuan UUPA mengenai warga negara asing yang setelah berlakunya UUPA ini menerima hak milik karena warisan, mereka harus melepas hak itu dengan batas waktu 1 tahun semenjak didapatkannya hak itu ataupun luruhnya kewarganegaraan, sebab upaya hukum yang dilakukan ahli waris eks warga negara Indonesia dalam melepas hak milik atas tanah yang diperoleh akibat warisan yaitu salah satunya dapat melakukan upaya mengajukan permohonan lagi menjadi warga negara Indonesia namun sesudah tiga tahun dari tanggal perkawinan sehingga apabila permohonan di ajukan maka ahli waris yang telah kembali menjadi warga negara Indonesia dapat menerima kembali haknya sebagai warga negara Indonesia.

\section{DAFTAR PUSTAKA}

Arliman S, L. (2017). Perkawinan Antar Negara Di Indonesia Berdasarkan Hukum Perdata Internasional. Kertha Patrika, 39(3), 176-192.

Charity, M. L. (2016). Urgensi Pengaturan Kewarganegaraan Ganda Bagi Diaspora Indonesia. Jurnal Konstitusi, 13(4), 809-827.

Djawas, M., \& Nurzakia. (2018). Perkawinan Campuran di Kota Sabang (Studi terhadap Faktor dan Persepi Masyarakat tentang Dampak Perkawinan Campuran). Samarah: Jurnal Keluarga Dan Hukum Islam, 2(2), 307-333.

Purangin, E. (1997). Hukum Waris. Raja Grafindo Persada.

Purnamasari, I. D. (2014). Kiat-kiat Cerdas, Mudah dan Bijak Memahami Masalah Hukum Waris. Mizan Pustaka.

Rampay, D. L. (2015). Hak Waris Anak dalam Perkawinan Campuran Berdasarkan Undang-Undang Nomor 12 Tahun 2006 tentang Kewarganegaraan. Jurnal Morality, 2(2).

Sebastian, A. T. (2018). Hak Ahli Waris Warga Negara Asing atas Obyek Waris Berupa Saham Perseroan Terbatas Penanaman Modal dalam Negeri. Ad'Adl, 10(2).

Sumardjono, M. S. (2009). Kebijakan Pertanahan. Kompas.

Supramono, G. (2012). Hukum Orang Asing di Indonesia. Sinar Grafika.

Yusticia, T. B. (2018). Kamus Istilah Hukum. C-klik Media. 